\title{
Effect of Exploratory Fitness Education on Social Skills
}

\author{
Risma Risma, Andang Rohendi \\ Universitas Galuh Ciamis \\ Ciamis, Indonesia \\ andreanada18@gmail.com, andangrohendi@gmail.com
}

\begin{abstract}
This study aimed to determine whether the exploratory fitness education effect toward students' social skills. The research method used is the method of experimental research method. The participants were 56 university students of Health and Recreation Educational Program FKIP Universitas Galuh Ciamis. Students' social skills were measured using social skills instruments adapted from the Social Skills Rating Scale which developed by Gresham and Elliott. After testing of statistical assumptions performed it is known that the data is normally distributed (pre-test and post-test $p=0.086 p=0.200$, which $p>0.05$ ) so that the data analysis uses paired samples $t$ test analysis. From the analysis results of the research is know that Sig. (2-tailed) of 0.003 , because the value of Sig. (2-tailed) is less than 0.05 , so it can be concluding that exploratory fitness education effect the social skills of students in PJKR Study Program FKIP Universitas Galuh Ciamis.
\end{abstract}

Keywords—social skill; exploratory fitness education

\section{INTRODUCTION}

The development of technology has an impact on people's lives, both positive impacts and negative impacts. The positive impact of technological development is the ease of getting information without limited distance and time. However, the negative side of this technology is that people become lazy to communicate directly. According to a survey conducted by MarkPlus Insight (dailysocial.net) on November 13, 2012 regarding internet users in Indonesia, there are three things that can support the statement about the number of people who communicate virtually. $40 \%$ of Internet users in Indonesia, around 24.2 million people access the Internet more than 3 hours per day. The majority of Internet users in Indonesia are aged 15 to 35 years. As well as approximately $56.4 \%$ of people including bargain hunters, people who can access the Internet to find information and everything for their needs in a long time.

Data from the Ministry of Communication and Information of the Republic of Indonesia states that Indonesia as one of the countries with the most people access the Internet in the world. In addition, there is also a research institution stating that Indonesia is ranked fifth in the list of the largest smartphone users in the world. In the data also mentioned that Indonesia occupies the top 5 country from all countries in the world with active internet users, as many as 47 million or around $14 \%$ of the total mobile users [1]. Based on the results of these surveys it can be seen that internet users in Indonesia are in the productive age group. If this internet usage is not accompanied by a sense of user responsibility, it is possible that the internet can be a serious problem for the community, especially for those productive age groups that are the hope of the nation.

Other phenomena that occur in Indonesia, aside from technological advances are the low active lifestyle. In addition of low physical fitness, physical inactivity also results in various non-infectious diseases and even death. Sport Development Index (SDI) in 2006 related with the fitness status of the Indonesian people, stated that $37.40 \%$ were in the category of very poor, $43.90 \%$ less, $13.55 \%$ moderate, and only $5.15 \%$ only the category is good and very good. This condition is mostly related with the low awareness of the community to carry out physical activities.

Information of physical activity from Basic Health Research (RISKESDAS), released by The National Institute of Health Research and Development stated that Indonesian people has low physical activities level, as much as $26.1 \%$. There are 22 provinces with a population of physical activity classified as less active above the Indonesian average. The number of Indonesian with sedentary behaviour $\geq 6$ hours per day is $24.1 \%$. The five provinces above the national average sedentary behaviour $\geq 6$ hours are Riau (39.1\%), North Maluku (34.5\%), East Java (33.9\%), West Java (33.0\%), and Gorontalo $(31.5 \%)$.

The decrease in lack of movement behaviour mainly occurs at the age of students who in fact have no formal learning, except for sports programs. A research regarding Physical activity of level 2 Community College students, reveal that the majority of respondents did not participate in regular physical activity. This condition is certainly very worrying, considering that at that age it should be a productive age with a variety of activities and quite a lot of task demands.

The development of technology and the low participation of physical activity in the productive age group are problems that must be immediately sought for a solution. Students belong to the productive age group which is expected to be a generation of qualified successors. Technological advances that occur in the community, including in student groups if used without a sense of responsibility, are feared to be a big problem in their development as a holistic human being. The skills to socialize 
are feared to be threatened. Though social skills are one of the skills that must be possessed by each individual.

The role of social skills requires many aspects to fulfil their needs, including developing in their psychological aspects. Therefore, human development is not only depending on the physical aspect but involves all aspects such as feeling, behaviour, maturity of thinking and the development of positive values [2].

The definition of social skills has been widely stated by experts. social skills are behaviours which individuals learn to conduct their interpersonal relationships to obtain environmental stimuli or maintain these environmental stimuli [3]. Other definition stated that social skills are verbal and nonverbal behaviours that bring effective individual interaction with others, which include: participating, observing by turns, being compatible, choosing, being friendly, and communicating with others [4,5].

Fitness education is a subcomponent of the total physical education program, which help students acquire knowledge and higher-order understanding of health-related physical fitness (the product), as well as habits of physical activity and other healthy lifestyles (the process) that lead to better health-related physical fitness, health and wellness. This study aimed to determine whether the exploratory fitness education effect toward students' social skills.

\section{METHODS}

\section{A. Study Design}

This study is using experimental method, with one group pre-test and post-test design.

\section{B. Participants and Procedures}

The participants in this study were students from Health and Recreation Physical Education Study Program in Galuh University, Ciamis. The number of samples for each group of samples was approximately 56 participants. Sampling in this research is by cluster random sampling.

\section{Instrument}

The instrument used in this study was adapted from the Social Scale Rating System (SSRS) developed by Frank M. Gresham and Stephen N. Elliott. Social skills instruments used in this study contain questions that consist of sub-indicators: cooperation, assertiveness, responsibility, empathy and selfcontrol.

\section{RESULT AND DISCUSSION}

Based on normality test, it is known that the pre-test data group is 0.086 and the post-test data group is 0.200 , so the pretest and post-test data groups are normally distributed. Since that the data is normally distributed, so to answer the hypothesis analysis is done by paired sample $t$ test analysis. Hypothesis testing is done based on paired sample $t$ test which is used to test the differences between two samples in pairs. Paired samples are interpreted as a sample with the same subject but experience two different treatments before and after the process. The data analysis showed that Sig. (2-tailed) of 0.003 , because the value of Sig. (2-tailed) is smaller than 0.05 , then $\mathrm{H} 0$ is rejected and $\mathrm{H} 1$ is accepted, so it can be concluded that exploratory fitness education affects students' social skills in students of PJKR Study Program FKIP Galuh Ciamis University.

Education is one of the instruments to help the students into individuals who are ready to socialize in community life. Formal education shapes students not only intelligently smart but emotionally and emotionally intelligent and develops comprehensively [6]. Physical education as part of comprehensive education has the potential to be able to contribute maximally in student development. Bailey revealed that the results of physical education can be understood in 5 domains of child development namely: (1) physical, (2) lifestyle, (3) affective, (4) social, (5) cognitive [7].

Physical education according to Sallis et al has been an integral part of the school curriculum for more than 100 years [8]. It is as stated that, 'Physical education, a school curricular subject over the past 100 years, has a number of goals, including providing students with the knowledge, skills, abilities, and confidence to be physically active throughout their lifetime' [9]. Physical fitness is often regarded as the main goal or impact expected from physical education subjects at school. "over the years, however, definition of fitness and specific program objectives have change substantially" [10].

Changes in the definition occur in accordance with the demands and goals expected from the curriculum program created. At present the fitness education curriculum model continues to reflect differences in variations in the philosophy of physical education and in the educational belief that increasing number of teachers have the responsibility to develop curriculum in their school environment.

Curriculum planners use fitness education models with the assumption that physical activity is essential for a healthy lifestyle. Regarding fitness education, the National Association for Sport and Physical Education defines that : Fitness education is a subcomponent of the total physical education program, focusing on helping students acquire knowledge and better understanding of health-related physical fitness (the product), as well as habits of physical activity and other healthy lifestyles (the process) that lead to good health-related physical fitness, health and wellness [11]. Based on the statement, fitness education is a total sub-component of the health program, which focused on helping students gain knowledge and convey a higher understanding of physical fitness related to health (products), as well as physical activity habits and other healthy lifestyles (process) which leads to physical fitness related to health, health and appearance.

Meanwhile Virgilio suggested that Fitness education is viewed as a comprehensive, multidisciplinary approach to helping children acquire knowledge, attitudes, beliefs, and behaviours for the promotion of long-term active, healthy manifestations within a quality physical education program [12]. Fitness education is seen as a comprehensive multidisciplinary approach to help students gain knowledge, attitudes, beliefs and behaviours to promote long-term active, healthy lifestyles in a quality. Fitness education has goals to 
develop knowledge about fitness, skills in activities with health benefits, and habits of regular exercise." similarly, all fitness education curricula are designed to build knowledge related to fitness, skills in activities with health benefits, and regular exercise habits [13].

Social skills are individuals or society member ability in establishing relationship with others and his problem solving ability with which a harmonious society can be achieved" dan "The social skill is the ability to interact with others in a given social context in specific ways that are socially acceptable or valued at the same time personality beneficial, mutually beneficial, of beneficial primarily to others" [14]

Organizational learning and forms of teaching are very important in the formation of social skills, helping to demonstrate different social situations and using skills in communicating and working together. Furthermore, Anderson et al explained that an effective social skills development program consists of two important elements, namely the social / behavioural learning approach and universal language or a set of stages that facilitate new learning behaviour, which is based on 4 pillars of education namely: (1) Learning to know , (2) Learning to do, (3) Learning to live together, (4) Learning to do [15].

Social skills as abilities that must be possessed by children develop naturally according to their growth. But in its development stage, social skills are learned by children from their daily interactions with others. That is, the development of children's social skills is not only formed in the school environment, but in all environments where he lives as a medium and means of learning. In its development, social skills are influenced by several factors, including the child's condition, age, interaction with the environment, gender, family socioeconomic, parental education, parental work, and number of siblings [16].

Learning approach by using cooperative learning model in this study provides equal opportunities for children to be able to participate in physical education learning. With intense interaction and communication with group members, students' social skills increase. Based on these explanations, it can be concluded that exploratory fitness education by using cooperative learning model in this study provide opportunities for students to develop interpersonal skills by interacting with friends in their study groups. Social skills act as the essence of successful performance both in the academic and in the life field [5]. Students with good social skills are able to face various challenges and adapt to circumstances and not depend on the people around them [17].

\section{CONCLUSION}

Based on this research it can be concluded that exploratory fitness education influences the social skills of students in students of PJKR Study Program FKIP Galuh Ciamis University.

\section{REFERENCES}

[1] A. Suherman, "Building the quality of national's life through physical, education," Speech for inauguration of UPI professors. Unpublished.

[2] M. Goudas, I. Dermitzaki, A. Leondari and S. Danish, "The effectiveness of teaching a life skills program in a physical education context," Eur J Psychol Educ., vol. XXI, pp. 429-438, 2006.

[3] E. Arslan, H. Yilmaz and Neslihan Durmusoglu-S, Social skills and emotional and behavioral traits of preschool children, vol. 39, no. 9, pp 1281-1288, 2011.

[4] M.G. Lavasani and F. Khandan, "Cooperative learning and social skills," Cypriot J Educ., vol. 2, pp. 61-74, 2011.

[5] E. Eldar and S. Ayvazo, "Educating through the physical-rationale," Education and Treatment of Children, vol. 32, no. 3, pp. 471-486, 2009.

[6] A. Suherman, Mulyana and Berliana, "An evaluation of government policy and program on sports and sport culture in Bandung," Int J Appl Bus Econ Res., vol. 14, no. 15, pp. 10845-10853, 2016.

[7] R. Bailey, "Physical education and sport in schools : a review of benefits and outcomes general article physical education and sport in schools : a review of benefits and outcomes," J of School Heal., vol. 76, pp. 397401, 2016.

[8] J.F. Sallis, T.L. McKenzie, M.W. Beets, A. Beighle, H. Erwin and S. Lee, "Physical education's role in public health: steps forward and backward over 20 years and hope for the future," Res Q Exerc Sport., vol. 83, no. 2, pp. 125-135, 2012.

[9] J.F. Sallis, T.L. Mckenzie, J.E. Alcaraz, B. Kolody, N. Faucette and M.F. Hovell, "The effects of a 2-year physical education program (SPARK) on physical activity and fitness in elementary school students," Am J Public Health, vol. 87, no. 8, pp. 1328-1334, 1997.

[10] L. Haerens, G. Cardon, I. De Bourdeaudhuij and D. Kirk, "Toward the development of a pedagogical model for health-based physical education" Quest, vol. 63, no. 3, pp. 321-338, 2011.

[11] NASPE, "Instructional framework for fitness education in physical education instructional framework for fitness education in PE ( Cont.)," Guid Doc, vol. 703, 2012

[12] S.J. Virgilio, Fitness education for children: a team approach, 1997.

[13] A.E. Jewett, "Curriculum theory in physical education," Int Rev Educ. 1989.

[14] M. Jurevičienė, I. Kaffemanienė and J. Ruškus, "Concept and structura components of social skills," Educ Phys Training, vol. 86, no. 3, pp. 42 52, 2012.

[15] D. Anderson-Butcher, E. Martin, L. Paluta and D. Gould, "Patterns of social skill development over-time among clusters of life sports participants," Child Youth Serv Rev. vol. 87, pp. 17-25, 2018.

[16] G. Crombie, "Gender differences: implications for social skills assessment and training," J Clin Child Psychol., vol. 17, no. 2, pp. 37 41, 2013.

[17] M. Jurevičienè, I. Kaffemanienė and J. Ruškus, "Concept and structural components of social skills," Educ Phys Training, vol. 86, no. 3, pp. 42 $52,2012$. 